\title{
The Action of Light on Nitrate and Nitrite Assimilation by the Marine Chlorophyte, Dunaliella tertiolecta (Butcher)
}

\author{
By B. R. GRANT \\ Division of Fisheries and Oceanography, CSIRO, Cronulla, N.S.W. Australia
}

(Accepted for publication I7 March 1967)

\begin{abstract}
SUMMARY
Light caused up to a 20 -fold increase in the rate of nitrate and nitrite assimilation by the marine chlorophyte Dunaliella tertiolecta. While higher rates of oxygen evolution were observed during both nitrate and nitrite assimilation, the extra oxygen released was not related to the amounts of nitrate or nitrite assimilated. Carbon dioxide was required for light to increase nitrate or nitrite assimilation; the addition of glucose did not overcome this requirement. The light intensities at which nitrate and nitrite assimilation reached their maximum rates were 300 and $1000 \mathrm{ft}$. candles respectively, while oxygen evolution and carbon fixation required i $800 \mathrm{ft}$. candles. In the presence of 3-(4-chlorophenyl)-I, I-dimethylurea $\left(\mathrm{IO}^{-4} \mathrm{M}\right)$, nitrate and nitrite assimilation were still increased by $30 \%$ in light, although oxygen evolution decreased to $2 \%$ of the control rate. Assimilation of nitrate and nitrite in light was decreased to $50 \%$ by sodium azide or potassium cyanide at $\mathrm{I}-5 \times 1 \mathrm{O}^{-5} \mathrm{M}$; oxygen evolution was less sensitive, requiring more than $3 \times 10^{-4} \mathrm{M}$ to decrease the evolution to $50 \%$. Azide and cyanide both blocked dark nitrate and nitrite assimilation but at slightly higher concentrations than those required in the light. Iodoacetate $\left(\mathrm{IO}^{-3} \mathrm{M}\right)$ decreased dark nitrate and nitrite assimilation to $2 \%$ and $38 \%$ of control values, respectively; but, in the light, nitrate assimilation was not affected and nitrite assimilation was decreased by only $35 \%$ at this concentration. It is concluded that the action of light in stimulating nitrate and nitrite assimilation cannot be explained on the basis of a single site of action as has been proposed for spinach chloroplasts and that two relatively independent sites exist in the living $D$. tertiolecta cell.
\end{abstract}

\section{INTRODUCTION}

That light stimulates nitrate and nitrite assimilation in unicellular algae, (Syrett, I962; Kessler, 1959) and in green leaves (Burstrom, I943) has been well documented since the original discovery by Warburg \& Negelein (I920). The explanation of this effect is not yet agreed upon. Warburg attributed the increase in assimilation rate as a permeability effect, and believed that in both light and dark, the reduction of nitrate to ammonia was coupled to respiration, and that the extra carbon dioxide production accompanying nitrate assimilation in the dark came from increased carbohydrate breakdown. The extra oxygen evolution observed in the light during nitrate assimilation was postulated to come from photolytic splitting of this carbon dioxide. With some minor modifications Warburg still adheres to this interpretation (Warburg, Krippahl \& Jetschmann, 1965).

Evans \& Nason (1953) demonstrated that the reduction of pyridine nucleotides by 
chloroplasts could be coupled to the reduction of nitrate by the addition of nitrate reductase. More recent work by Paneque, Ramirez, Del Campo \& Losada (1964) and Losada, Ramirez, Paneque \& Del Campo (I965) showed that isolated spinach chloroplasts could reduce both nitrate and nitrite to ammonia in the light or, when a bacterial hydrogenase and hydrogen were added, in the dark (Del Campo, Paneque, Ramirez \& Losada, I965). This work strengthened an alternative theory of the action of light on nitrate assimilation proposed by van Niel, Allen \& Wright (I953). This was that light increased the rate of nitrate reduction by providing directly increased amounts of photoreductant, rather than in the indirect manner proposed by Warburg. The extra oxygen production observed in the light was postulated to come from the water-splitting reaction and increased rates of electron flow resulted from the extra electrons going to reduce nitrate after the requirements of the carbon fixing system were saturated. Evidence for this was provided by the finding that nitrate assimilation inhibits carbon dioxide assimilation at low light intensities but not at high intensities. The work of Losada et al. (1965) and Paneque et al. (1964) indicated that a flavoprotein was the photoreductant for nitrate assimilation and that ferredoxin was the photoreductant in nitrite assimilation.

In spite of the apparently strong evidence in favour of the theory of direct action of light, there are still some experimental results which are difficult to explain by this theory. The most important is the requirement for carbon dioxide, if nitrate and nitrite assimilation in the light are to proceed at maximum rates (Davis, 1953; Kessler, 1964; Warburg et al. 1965). There is also a report by Bongers (I958) that nitrate and nitrite assimilation inhibit carbon fixation even at light intensities which are saturating for photosynthesis. Further, Hattori (1962) reported that nitrate and nitrite assimilation saturate at lower intensities than does oxygen evolution. Because of these anomalies it was felt that further experimental work on the action of light on nitrate and nitrite assimilation should be done. In the present paper, results obtained with the green unicellular alga Dunaliella tertiolecta are presented. This alga is an inhabitant of salt water estuaries and belongs to the order Volvocales; the green algae investigated to date belong to the order Chlorococcales. It was hoped that in addition to providing data on the fundamental problem of nitrate assimilation, some comparative data for other species of green algae might be obtained.

\section{METHODS}

Organism. A strain of Dunaliella tertiolecta (Butcher) obtained from Dr Mary Parke, Plymouth, U.K., was used in these experiments.

Culture methods. Organisms were grown in batch cultures of 21 . contained in 51 . Haffkine flasks. The composition of the medium was as follows: filtered sea water, salinity 28-30\%, $950 \mathrm{ml}$; distilled water, $50 \mathrm{ml}$.; $\mathrm{KNO}_{3}, 75 \mathrm{mg}$.; $\mathrm{NaH}_{2} \mathrm{PO}_{4} \cdot 2 \mathrm{H}_{2} \mathrm{O}$, Io mg.; Fe citrate, $\mathrm{I} \cdot 5 \mathrm{mg}$.; citric acid, $\mathrm{I} \cdot 5 \mathrm{mg}$.; $\mathrm{MnSO}_{4} \cdot 4 \mathrm{H}_{2} \mathrm{O}, 360 \mu \mathrm{g}$.; $\mathrm{ZnSO}_{4} \cdot 7 \mathrm{H}_{2} \mathrm{O}$, $44 \mu \mathrm{g}$.; $\mathrm{CoCl}_{2} .6 \mathrm{H}_{2} \mathrm{O}, 20 \mu \mathrm{g}$; $\mathrm{CoSO}_{4} \cdot 5 \mathrm{H}_{2} \mathrm{O}$, $19 \mu \mathrm{g}$; thiamine hydrochloride, $200 \mu \mathrm{g}$; biotin, I $\mu \mathrm{g}$.; vitamin $\mathrm{B}_{12}$ (cobalamin) I $\mu \mathrm{g}$. The vitamins and phosphate were sterilized separately in the distilled water and added to the remainder of the media after cooling.

Growth conditions. Cultures were grown under illumination from fluorescent lamps which provided a light intensity of $400 \mathrm{ft}$. candles, and gassed with a slow stream of air $+5 \%(\mathrm{v} / \mathrm{v}) \mathrm{CO}_{2}$. Temperature was maintained at $22^{\circ} \pm \mathrm{I}^{\circ}$. 
Preparation of experimental suspensions of organisms. Organisms were harvested whilst in their logarithmic growth phase (3-4 days) by centrifugation at $500 \mathrm{~g}$ for $20 \mathrm{~min}$. at $5^{\circ}$. Packed organisms were resuspended in $100 \mathrm{ml}$. of $3 \%(\mathrm{w} / \mathrm{v}) \mathrm{NaCl}$ solution and centrifuged. This was repeated with $50 \mathrm{ml}$. of $\mathrm{NaCl}$ solution and after this organisms were resuspended in sufficient $\mathrm{NaCl}$ solution to provide a concentration of $0.4-0.5 \mathrm{mg}$. total chlorophyll $/ \mathrm{ml}$. The suspension was then held for $30-$ $60 \mathrm{~min}$. in the dark at room temperature before further use. The concentration of chlorophyll used was equivalent to $5-8 \times 10^{7}$ organisms $/ \mathrm{ml}$. suspension. (No damage to cells was observed by this preparation and cells were motile at time of each experiment.)

Measurements. Chlorophyll was determined by the method of Whatley \& Arnon (1963). Total cell nitrogen was determined by Kjeldahl digestion followed by estimation of ammonia by the method of Newell \& Dal Pont (1964). Numbers of organisms were determined by counting with a Petroff-Hauser slide after immobilizing with one drop of Bouins fluid $/ \mathrm{ml}$. diluted suspension. Nitrate and nitrite assimilation was determined by measurement of nitrate or nitrite present in the sample of reaction mixture from which the cells had been centrifuged before and after the experimental period. Nitrate was estimated by reduction to nitrite on a cadmium-mercury column (Morris \& Riley, 1963) with the ammonia + ammonium chloride buffer of Grasshof (1964). Nitrite was estimated by pipetting the sample of reaction mixture directly into $3.5 \mathrm{ml}$. of I $\%(\mathrm{w} / \mathrm{v})$ sulphanilic acid in $2.5 \mathrm{~N}-\mathrm{HCl}$, removing debris after $5 \mathrm{~min}$. by centrifugation and adding a sample to a suitable volume of $0.02 \%(\mathrm{w} / \mathrm{v}) \mathrm{N}$-I-naphthylethylenediamine and determining the extinction at $540 \mathrm{~nm}(\mathrm{~m} \mu)$. Carbon assimilation was determined by adding I $\mu$ mole $\mathrm{Na}^{14} \mathrm{HCO}_{3}\left(4 \cdot 2 \times \mathrm{IO}^{4} \mathrm{dpm}\right)$ to the reaction mixture at the beginning of the experiment, and then at its conclusion pipetting a sample into $5 \mathrm{ml} .5 \%$ (v/v) Io N-HCl in ethanol. The solution was warmed to expel dissolved $\mathrm{CO}_{2}$ and a sample counted in a liquid scintillation counter, with the solvent described by Bray (1960).

Experimental conditions. Nitrate and nitrite assimilation measurements were done in a Warburg apparatus at $20^{\circ}$. Illumination was provided by incandescent lamps and was between 2500 and $3000 \mathrm{ft}$. candles intensity. Gas exchange was measured during the experiments. The complete reaction mixture in the flasks contained the following: suspension of organisms $\mathrm{I} \cdot 0 \mathrm{ml}$; 位 buffer $(\mathrm{pH} 7 \cdot 6)$, $125 \mu$ moles; $\mathrm{KNO}_{3}$ or $\mathrm{KNO}_{2}$, $2.0 \mu$ moles; $\mathrm{NaHCO}_{3} 40 \mu$ moles, and $3 \%(\mathrm{w} / \mathrm{v}) \mathrm{NaCl}$, to total volume of $2.0 \mathrm{ml}$. Where carbon dioxide was omitted, $\mathrm{NaHCO}_{3}$ was omitted and $0.15 \mathrm{ml}$. of $20 \%$ $(\mathrm{w} / \mathrm{v}) \mathrm{KOH}$ added to centre well. Nitrate or nitrite was added to the reaction mixture at zero time by tipping from the flask side arm.

\section{RESULTS}

\section{The effect of light on nitrate and nitrite assimilation by Dunaliella tertiolecta}

Light increased the rate of nitrate and of nitrite assimilation by Dunaliella tertiolecta, although the increase varied from one batch of organisms to another. During the experimental period both dark and light assimilation were linear. Although the rates of both nitrate and nitrite assimilation varied between wide limits the rate of nitrite assimilation was generally higher. This agreed with the observation that nitrite did not accumulate in the suspending medium when nitrate was being assimilated. 
Gas exchange accompanying nitrate and nitrite assimilation. Although in all but one of the experiments recorded in Tables I, 2 and Fig. 1, nitrate or nitrite assimilation was accompanied by increased oxygen evolution, there was no consistency between the amount of extra oxygen evolved and the amount of nitrate or nitrite assimilated. For the purpose of discussion it is reasonable to assume that nitrate (or nitrite) assimilated was the equivalent of nitrate reduced, for the following reasons: (I) Dunaliella tertiolecta did not store either nitrate or nitrite; (2) excretion of nitrite or other products of incomplete nitrate reduction into the medium was not observed (B. Newell, G. Dal

\section{Table I. Effect of light on nitrate assimilation by Dunaliella tertiolecta and the resultant oxygen evolution}

Each vessel contained in a total of $2 \mathrm{ml}$. the following: $0.5 \mathrm{mg}$. chlorophyll, I $25 \mu$ moles tris$\mathrm{HCl}$ buffer $(\mathrm{pH} 7.6), 40 \mu$ moles $\mathrm{NaHCO}_{3}$, and 0.5 or 0.7 mmoles $\mathrm{NaCl}$. Where nitrate was supplied it was as $2 \mu$ moles $\mathrm{KNO}_{3}$. The experimental period was 30 or $40 \mathrm{~min}$. All values are expressed as $\mu$ moles $/ \mathrm{hr} / \mathrm{mg}$. chlorophyll.

\begin{tabular}{|c|c|c|c|c|c|}
\hline \multirow[b]{2}{*}{ Expt. } & \multicolumn{2}{|c|}{$\mathrm{NO}_{3}$ uptake } & \multicolumn{2}{|c|}{$\mathrm{O}_{2}$ evolution } & \multirow{2}{*}{$\begin{array}{c}\text { Extra } \\
\mathrm{O}_{2} / \mathrm{NO}_{3} \\
\text { uptake }\end{array}$} \\
\hline & Light & Dark & Control & $+\mathrm{NO}_{3}$ & \\
\hline 32 & $2 \cdot 18$ & 0.92 & $38 \cdot 4$ & $39 \cdot 2$ & 0.6 \\
\hline 53 & $I \cdot 62$ & 0.14 & $5 I \cdot 6$ & $58 \cdot 2$ & 4.5 \\
\hline 55 & $3 \cdot 34$ & $I \cdot 30$ & $3 I \cdot 2$ & $30 \cdot 4$ & -0.8 \\
\hline 57 & 0.75 & 0.43 & $4 I \cdot 2$ & $4 I \cdot 6$ & $\mathrm{I} \cdot 3$ \\
\hline 64 & $3 \cdot 20$ & 0.60 & $32 \cdot I$ & $42 \cdot 3$ & 3.9 \\
\hline 79 & 3.68 & 0.00 & $63 \cdot 6$ & $7 I \cdot 3$ & $2 \cdot I$ \\
\hline 92 & $2 \cdot 75$ & 0.00 & $68 \cdot 0$ & $70 \cdot 0$ & 0.7 \\
\hline 93 & $3 \cdot 38$ & 0.00 & $92 \cdot 0$ & $100 \cdot 0$ & $2 \cdot 4$ \\
\hline 94 & $3 \cdot 10$ & $0.5 \mathrm{I}$ & $5 \mathrm{I} \cdot 7$ & $56 \cdot 5$ & $2 \cdot 2$ \\
\hline 95 & 3.00 & 0.25 & $43 \cdot 0$ & $50 \cdot 0$ & $2 \cdot 5$ \\
\hline
\end{tabular}

Table 2. Effect of light on nitrite assimilation by Dunaliella tertiolecta and the resultant oxygen evolution

Experimental conditions were as for Table I except that $2 \mu$ moles $\mathrm{KNO}_{2}$ were substituted for $\mathrm{KNO}_{3}$. All values are expressed as $\mu$ moles $/ \mathrm{hr} / \mathrm{mg}$. chlorophyll.

\begin{tabular}{|c|c|c|c|c|c|}
\hline \multirow[b]{2}{*}{ Expt. } & \multicolumn{2}{|c|}{$\mathrm{NO}_{2}$ uptake } & \multicolumn{2}{|c|}{$\mathrm{O}_{2}$ evolution } & \multirow{2}{*}{$\begin{array}{c}\text { Extra } \\
\mathrm{O}_{2} / \mathrm{NO}_{2} \\
\text { uptake }\end{array}$} \\
\hline & Light & Dark & Control & $+\mathrm{NO}_{2}$ & \\
\hline $7 \mathrm{I}$ & $2 \cdot 00$ & 0.60 & 38.0 & $40 \cdot 0$ & $x \cdot 4$ \\
\hline 79 & $8 \cdot 00$ & $3 \cdot 85$ & $38 \cdot 5$ & $50 \cdot 0$ & $2 \cdot 7$ \\
\hline 80 & $6 \cdot 80$ & $3 \cdot 66$ & $55^{\circ} 8$ & $6 I \cdot 0$ & $I \cdot 6$ \\
\hline 88 & $2 \cdot 30$ & 0.00 & $118 \cdot 0$ & 125.0 & $3 \cdot 2$ \\
\hline 99 & $2 \cdot 62$ & 0.86 & $33 \cdot 5$ & $37 \cdot 2$ & $2 \cdot I$ \\
\hline 100 & $5 \cdot 25$ & $\mathrm{I} \cdot 59$ & $59 \cdot 3$ & $79 \cdot 5$ & $5 \cdot 5$ \\
\hline
\end{tabular}

Pont and B. R. Grant, unpublished observation). The gas evolution rates presented in these experiments were linear during the experimental periods; neither nitrate nor nitrite was exhausted in that time. Gas evolution has been corrected for gas uptake in dark controls in these experiments. Whilst it was not possible to test in each experiment that the gas evolved was oxygen, two separate experiments with acid chromous chloride in the side arm showed no gas evolution and the chromous chloride rapidly changed colour from blue to green.

Requirement for carbon dioxide. When bicarbonate was omitted from the reaction 
mixture and potassium hydroxide was added to the centre well of the reaction flask neither nitrate nor nitrite assimilation was increased by light. Although in these experiments some gas evolution took place during the first 10 min. of illumination, it ceased abruptly at or before Io min. Since the controls without nitrate or nitrite behaved in the same manner, this was not due to assimilation of nitrate in the absence of $\mathrm{CO}_{2}$. Since the gas evolution and nitrate assimilation decreased with longer dark pre-incubation periods, it was probably due to small amounts of carbon dioxide in the system (Table 3). Glucose (Io $\mu$ moles/vessel) added to the reaction mixture did not overcome the requirement for carbon dioxide, although it increased nitrate assimilation and $\mathrm{O}_{2}$ production (Table 4).

\section{Table 3. Effect of carbon dioxide on nitrate and nitrite assimilation by Dunaliella tertiolecta}

Each vessel contained in a total of $2 \mathrm{ml}$. the following: $0.5 \mathrm{mg}$. chlorophyll, $125 \mu \mathrm{moles}$ tris- $\mathrm{HCl}$ buffer $\left(\mathrm{pH} 7.6\right.$ ), $2 \mu$ moles $\mathrm{KNO}_{3}$ or $\mathrm{KNO}_{2}, 0.5$ or $0.7 \mathrm{mmoles} \mathrm{NaCl}$. Control vessels contained, in addition, $40 \mu$ moles $\mathrm{NaHCO}_{3}$ while $\mathrm{CO}_{2}-$ free vessels contained $0.15 \mathrm{ml} .20 \% \mathrm{KOH}$ in centre wells. Experimental period $40 \mathrm{mins}$. All values given as $\mu$ moles $/ \mathrm{hr} / \mathrm{mg}$. chlorophyll.

$\begin{array}{lcccc} & \begin{array}{c}\mathrm{NO}_{3} \\ \text { assimilated }\end{array} & \mathrm{O}_{2} \text { evolved } & \begin{array}{c}\mathrm{NO}_{2} \\ \text { assimilated }\end{array} & \mathrm{O}_{2} \text { evolved } \\ \text { Air }+\mathrm{CO}_{2}+\text { light } & 2 \cdot 50 & 68 \cdot 0 & 4 \cdot 00 & 48 \cdot 2 \\ \text { Air }-\mathrm{CO}_{2}+\text { light } & 0 \cdot 10 & -{ }^{*} & \mathrm{I} \cdot 00 & \text { * }^{*} \\ \text { Air }+\mathrm{CO}_{2}+\text { dark } & 0.00 & -6 \cdot 4 & \mathrm{I} \cdot 20 & -3 \cdot 3 \\ \text { Air }-\mathrm{CO}_{2}+\text { dark } & 0.00 & -7 \cdot 4 & \mathrm{I} \cdot 20 & -6 \cdot 0\end{array}$

* A total of $\mathrm{I} \cdot 5 \mu$ moles $\mathrm{O}_{2}$ was evolved in the experiment with $\mathrm{NO}_{3}$ and $3.5 \mu$ moles $\mathrm{O}_{2}$ with $\mathrm{NO}_{2}$; but evolution ceased after 5 and 10 mins., respectively, and was identical in amount with controls in which $\mathrm{NO}_{3}$ and $\mathrm{NO}_{2}$ were absent.

Table 4. Effect of glucose on nitrate and nitrite assimilation by Dunaliella tertiolecta

Each vessel contained in $2 \mathrm{ml}$, organisms containing $0.5 \mathrm{mg}$. chlorophyll, $125 \mu$ moles tris- $\mathrm{HCl}$ buffer ( $\mathrm{pH} \mathrm{7}_{7} \cdot 6$ ), 0.5-0.7 mmoles $\mathrm{NaCl}, 40 \mu$ moles $\mathrm{NaHCO}_{3}$, and $2 \mu$ moles of either $\mathrm{KNO}_{3}$ or $\mathrm{KNO}_{2}$; $10 \mu$ moles D-glucose were added where indicated. Where no $\mathrm{CO}_{2}$ was required $\mathrm{NaHCO}_{3}$ was omitted and $0.15 \mathrm{ml} .20 \%(\mathrm{w} / \mathrm{v}) \mathrm{KOH}$ was added to centre well. Gas phase air $\pm \mathrm{CO}_{2}$. All values in $\mu$ moles $/ \mathrm{hr} / \mathrm{mg}$. chlorophyll.

\begin{tabular}{|c|c|c|c|c|}
\hline Conditions & $\begin{array}{c}\mathrm{NO}_{3} \\
\text { assimilated }\end{array}$ & $\mathrm{O}_{2}$ evolved & $\begin{array}{c}\mathrm{NO}_{2} \\
\text { assimilated }\end{array}$ & $\mathrm{O}_{2}$ evolved \\
\hline $\mathrm{CO}_{2}+$ light & 0.9 & $42 \cdot 2$ & $2 \cdot 5$ & $48 \cdot 4$ \\
\hline $\mathrm{CO}_{2}+$ light + glucose & $1 \cdot 5$ & $47 \cdot 8$ & $2 \cdot 6$ & $46 \cdot 3$ \\
\hline Light & $0 \cdot 2$ & $3 \cdot I$ & 0.2 & $2 \cdot 6$ \\
\hline Light + glucose & 0.2 & $3 \cdot 7$ & 0.2 & 4.4 \\
\hline $\mathrm{CO}_{2}+$ dark & 0.0 & $-I \cdot 7$ & 0.0 & $-4 \cdot 2$ \\
\hline $\mathrm{CO}_{2}+$ dark + glucose & $0 \cdot I$ & $-I \cdot 9$ & 0.0 & $-4 \cdot 8$ \\
\hline Dark & 0.0 & -0.6 & 0.0 & $-6 \cdot 7$ \\
\hline Dark + glucose & 0.0 & $-2 \cdot 2$ & 0.0 & $-6 \cdot 4$ \\
\hline
\end{tabular}

\section{The effect of inhibitors}

The inhibitor of photosynthesis 3-(4-chlorophenyl)-I, I-dimethyl urea (CMU) did not decrease oxygen evolution and nitrate and nitrite assimilation equally. An inhibitor concentration at $\mathrm{IO}^{-4} \mathrm{M}$ decreased oxygen evolution to $2 \%$ of the control rate; but nitrate and nitrite assimilation continued at 25 and $4 \mathrm{I} \%$ of the control rates. Lower 
concentrations of CMU showed an even more marked difference in sensitivity between the two systems (Table 5). Potassium cyanide and sodium azide were even more effective in inhibiting nitrate and nitrite assimilation than they were in inhibiting photosynthetic

Table 5. Effect of CMU on nitrate and nitrite assimilation by Dunaliella tertiolecta and oxygen evolution

Experimental conditions as described under Table I except that $0.02 \mathrm{ml}$. ethanol or ethanol solution of 3-(4-chlorophenyl)-I,I-dimethylurea (CMU) was added to each vessel. All values in $\mu$ moles $/ \mathrm{hr} / \mathrm{mg}$. chlorophyll. Time of experiments: $30 \mathrm{mins}$.

\begin{tabular}{|c|c|c|c|c|}
\hline & $\mathrm{NO}_{3}$ assimilated & $\mathrm{O}_{2}$ evolved & $\mathrm{NO}_{2}$ assimilated & $\mathrm{O}_{2}$ evolved \\
\hline $\begin{array}{l}\text { Control light } \\
+ \text { CMU }\end{array}$ & $2 \cdot 8 \mathrm{I}$ & $56 \cdot 3$ & 4.53 & $89 \cdot 0$ \\
\hline $\mathrm{IO}^{-7} \mathrm{M}$ & 3.27 & $5 I \cdot 9$ & $4 \cdot 48$ & $86 \cdot 0$ \\
\hline $10^{-6} M$ & $2 \cdot 92$ & $43 \cdot 9$ & 4.39 & $65 \cdot 2$ \\
\hline $\mathrm{IO}^{-5} \mathrm{M}$ & $2 \cdot 22$ & 3.7 & $3 \cdot 44$ & $-I \cdot 4$ \\
\hline $\mathrm{IO}^{-4} \mathbf{M}$ & I. 69 & $-3 \cdot 2$ & $2 \cdot 3 \mathrm{I}$ & $-6 \cdot 9$ \\
\hline $\begin{array}{l}\text { Control dark } \\
+\mathrm{CMU}\end{array}$ & $\mathrm{I} \cdot 30$ & $-4 \cdot 2$ & I. 47 & $-8 \cdot 0$ \\
\hline $10^{-7} \mathrm{M}$ & $\mathrm{I} \cdot 60$ & $-4 \cdot I$ & $1 \cdot 38$ & $-7 \cdot 5$ \\
\hline $10^{-6} \mathrm{M}$ & $\mathrm{I} \cdot 20$ & $-4 \cdot I$ & $1 \cdot 38$ & $-8 \cdot 5$ \\
\hline $\mathrm{IO}^{-5} \mathrm{M}$ & $I \cdot 10$ & $-4 \cdot 4$ & $I \cdot 38$ & $-7 \cdot 4$ \\
\hline $10^{-4} M$ & $I \cdot 20$ & $-4 \cdot 4$ & $I \cdot 38$ & - II 0 \\
\hline
\end{tabular}

Table 6. Effect of potassium cyanide and sodium azide on oxygen evolution and nitrate or nitrite assimilation

\begin{tabular}{cccc} 
Inhibitor & $\begin{array}{c}\mathrm{O}_{2} \text { evolution or } \\
\text { uptake }\end{array}$ & $\mathrm{NO}_{3}$ assimilation & $\mathrm{NO}_{2}$ assimilation \\
$\mathrm{KCN}$ light & $3 \times 10^{-4 *}$ & $\mathrm{I} \times \mathrm{I}^{-5}$ & $\mathrm{I} \times \mathrm{I}^{-5}$ \\
$\mathrm{KCN}$ dark & $\mathrm{I} \times \mathrm{I}^{-3}$ & $\mathrm{I} \times \mathrm{IO}^{-5}$ & $5 \times \mathrm{I}^{-4}$ \\
$\mathrm{NaN}_{3}$ light & $>\mathrm{I} \times \mathrm{IO}^{-3}$ & $5 \times \mathrm{IO}^{-5}$ & $5 \times \mathrm{I}^{-5}$ \\
$\mathrm{NaN}_{3}$ dark & $>\mathrm{I} \times \mathrm{IO}^{-3}$ & $\mathrm{I} \times \mathrm{IO}^{-4}$ & $5 \times \mathrm{I}^{-4}$ \\
\multicolumn{4}{r}{} \\
& * molar concentrations giving $50 \%$ inhibition.
\end{tabular}

Table 7. Effect of iodoacetate on nitrate and nitrite assimilation by Dunaliella tertiolecta

Experimental conditions as for Table I. All rates in $\mu$ moles $/ \mathrm{hr} / \mathrm{mg}$. chlorophyll

$\begin{array}{lcccc}\text { Light } & \begin{array}{c}\mathrm{NO}_{3} \\ \text { assimilated }\end{array} & \mathrm{O}_{2} \text { evolved } & \begin{array}{c}\mathrm{NO}_{2} \\ \text { assimilated }\end{array} & \mathrm{O}_{2} \text { evolved } \\ \quad \text { Control } & 3 \cdot 20 & 36 \cdot 2 & 5 \cdot 25 & 87 \cdot 0 \\ \quad \text { +iodoacetate } \mathrm{IO}^{-4} \mathrm{M} & 3 \cdot 80 & 65 \cdot 0 & 5 \cdot 25 & 80 \cdot 0 \\ \quad \text { tiodoacetate } \mathrm{IO}^{-3} \mathrm{M} & 3 \cdot 30 & 52 \cdot 0 & 3 \cdot 45 & 58 \cdot 3 \\ \text { Dark } & 0 \cdot 73 & -7 \cdot 2 & \mathrm{I} \cdot 58 & -7 \cdot 7 \\ \quad \text { Control } & 0 \cdot 0 \mathrm{I} & -5 \cdot \mathrm{I} & \mathrm{I} \cdot \mathrm{I} & -7 \cdot 2 \\ \quad \text { +iodoacetate } \mathrm{I0}^{-4} \mathrm{M} & 0 \cdot 02 & -7 \cdot 2 & 0 \cdot 6 & -5 \cdot \mathrm{I} \\ \quad \text { +iodoacetate } \mathrm{IO}^{-3} \mathrm{M} & 0.02 & & & \end{array}$

oxygen evolution. At $\mathrm{IO}^{-3} \mathrm{M}$ (the highest concentration tested) sodium azide decreased photosynthetic oxygen evolution by only $20 \%$ (Table 6 ). Sodium iodoacetate inhibited nitrate and nitrite assimilation in the dark but not in the light. While it is not possible now to be certain that this effect was not due to destruction of the inhibitor in the light, there seems to be evidence for two separate paths of nitrate and nitrite assimilation 
(Table 7). Sodium amytal, 2,4-dinitrophenol and $p$-chloromercuric-benzoate were without effect at the highest concentrations tested $\left(5 \times \mathrm{IO}^{-4} \mathrm{M}\right)$.

The effect of light intensity on nitrate and nitrite assimilation. The light intensity required to saturate nitrate and nitrite assimilation was much lower than that required to saturate oxygen evolution and carbon fixation. Since the light intensity was varied by using neutral density filters the effect was not due to a change in spectral characteristics of the light source. The actual maximum rates of the reactions shown in Fig. 2 were nitrate assimilation $2.5 \mu$ moles $/ \mathrm{hr} / \mathrm{mg}$. chlorophyll; nitrite, $5.5 \mu \mathrm{moles} / \mathrm{hr} / \mathrm{mg}$. chlorophyll; oxygen, $40 \mu \mathrm{moles} / \mathrm{hr} / \mathrm{mg}$. chlorophyll and 800 counts $/ \mathrm{min}$. per sample for cell carbon.

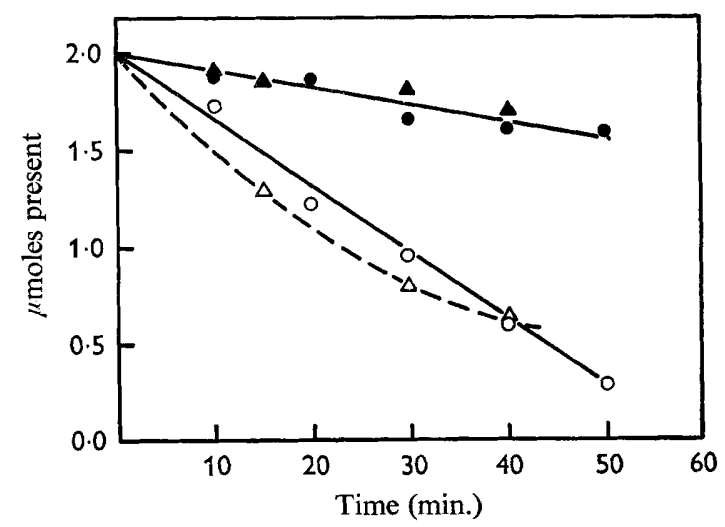

Fig. I. Dunaliella tertiolecta. Rate of nitrate and nitrite assimilation in light and dark. $\bigcirc$, nitrate light; $\bullet$, nitrate dark; $\triangle$, nitrite light; $\boldsymbol{\Delta}$, nitrite dark.

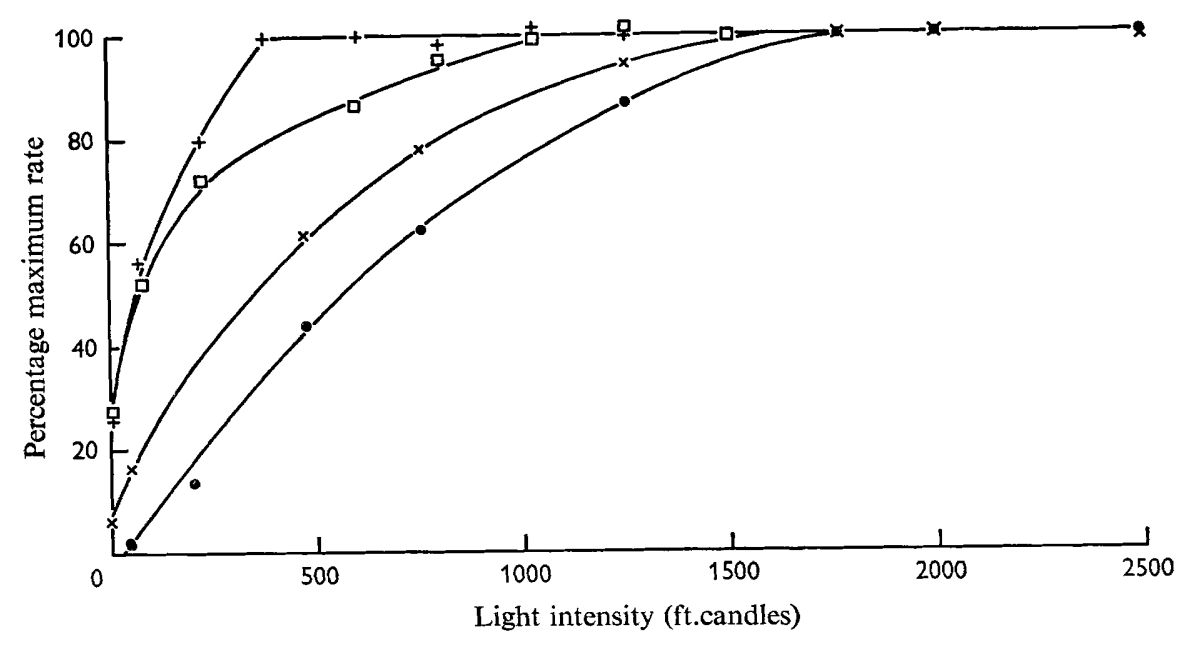

Fig. 2. Dunaliella tertiolecta. Effect of light intensity on nitrate assimilation, nitrite assimilation and oxygen evolution.,$+-+ \mathrm{NO}_{3}$ assimilation; $\square-\square, \mathrm{NO}_{2}$ assimilation; $\times-\times, \mathrm{CO}_{2}$ assimilation; $-\longrightarrow, \mathrm{O}_{2}$ production. 


\section{DISCUSSION}

Before attempting to interpret these results it is important to determine to what extent they are supported by those of other workers. Bongers (1958) and Davis (I953) showed that 2.0 moles extra oxygen were produced per mole nitrate assimilated in the light. However, Warburg \& Negelein (1920; see table XII, p. 90) found ratios between 3.7 and $6.0 \mathrm{O}_{2}$ per mole of $\mathrm{NH}_{4}$ produced, though in a later publication (Warburg et al. 1965) it was claimed that the 2.0: I stoichiometry was established. Hattori (I962) did not find the 2 : I stoichiometry value with nitrate, although he found the expected I.5: I stoichiometry value with nitrite. However, in both this paper and in a later publication (Fujita \& Hattori, 1963), it was stated that a $2 \cdot 0$ : I ratio of $\mathrm{O}_{2}: \mathrm{NO}_{3}$ was established. Since Davis (1953) did not measure nitrate assimilated, Bongers (I958), remains the one unambiguous report in the literature with the theoretical stoichiometry, which the author could find. It is therefore perhaps not surprising that in the results presented in the present paper the $\mathrm{O}_{2}: \mathrm{NO}_{3}$ ratio varied from 0.6 to 4.5 .

By contrast the $\mathrm{I} \cdot 5$ : I ratio $\mathrm{O}_{2}: \mathrm{NO}_{2}$ is fairly well documented. In addition to Bonger's (1958) work, Hattori (1962) and Kessler (1964) both reported experimental confirmation of this figure. As Dunaliella tertiolecta did not give this stoichiometry it apparently behaves differently from the species of algae investigated by these workers. Where hydrogen uptake has been studied and related to nitrate and nitrite reduction, the expected stoichiometry of $3 \cdot 0: \mathrm{I} \mathrm{H}_{2}: \mathrm{NO}_{2}$ was found (Kessler, I957; Hattori, 1963; Stiller, 1966). However, in the investigation with nitrate Kessler reported low rates of $\mathrm{H}_{2}$ uptake and difficulty in establishing the expected 4: I value.

The evidence for the requirement for $\mathrm{CO}_{2}$ for nitrate and nitrite assimilation in the light was mentioned in the introduction to this paper. Dunaliella tertiolecta appears to be more strict in this requirement than Ankistrodesmus or Chlorella. The failure of glucose to replace $\mathrm{CO}_{2}$ in $D$. tertiolecta in contrast to Davis's (1953) results with Chlorella may be due to the inability of $D$. tertiolecta to assimilate glucose at an appreciable rate. Preliminary experiments with ${ }^{14} \mathrm{C}$-labelled glucose, whilst not definite, support this postulate. Reports of nitrate and nitrite assimilation in the absence of $\mathrm{CO}_{2}$ are those of Kok (I95I) and Bongers (1958); as Kessler (I964) points out, Bonger's results are ambiguous since under his experimental conditions rapid production of $\mathrm{CO}_{2}$ by respiration was possible.

The chlorophenyl dimethylurea CMU has been shown to inhibit photosynthesis by blocking electron transport in the neighbourhood of the water-splitting reaction (Gingras \& Lemasson, 1965). An inhibitory effect of CMU on nitrite assimilation was reported by Hattori (1962); however, since he used different systems for measuring the effect of CMU on nitrite assimilation and on photosynthesis his results are not comparable to those presented in the present paper. It was reported by Paasche (1965) that although coccolithophore formation in Cyclotella nana was dependent on light it was not as sensitive to $\mathrm{CMU}$ as was $\mathrm{O}_{2}$ evolution, implying that light was affecting metabolism in ways other than simply by providing energy for photosynthesis. The effect of azide and KCN are consistent with the results obtained by Hattori (1962) and Losada et al. (1965), and are explicable on the basis of differential enzyme sensitivity. Both the results of Hattori (I962) and Bongers (1958) show that nitrate and nitrite assimilation saturate below the light intensity required to saturate photosynthtic oxygen evolution or carbon dioxide fixation. Thus with the single exception, that of a 
failure to find the expected $\mathrm{I} \cdot 5: \mathrm{I} \mathrm{O}_{2}: \mathrm{NO}_{2}$ ratio in the light, the results presented in this paper agree with findings of most other workers who have investigated nitrate or nitrite assimilation by algae.

The question now arises whether these results can be explained by the scheme put forward by Losada et al. (1965) from their work on reconstituted spinach chloroplast systems. This scheme is itself a development of that originally proposed by van Niel et al. (1953). In its simplest form this system would show two experimentally demonstrable features. First, at saturating light intensities $2 \cdot 0$ moles extra $\mathrm{O}_{2}$ would be produced per mole of $\mathrm{NO}_{3}$ assimilated to $\mathrm{NH}_{4}$ and $\mathrm{I}_{5} \cdot 5$ moles $\mathrm{O}_{2}$ for every mole of $\mathrm{NO}_{2}$. In the absence of $\mathrm{CO}_{2}$ the stoichiometry would hold even at non-saturating light intensities. Secondly, any inhibition of photosynthetic electron flow should decrease oxygen evolution and nitrate and nitrite assimilation to the same degree. It is clear that the present results, together with most of those of other workers, do not support this simple model in whole organisms. By making several assumptions it is possible to reconcile some of these results with the Losada scheme. The requirement for $\mathrm{CO}_{2}$ might be explained by the already known requirement of $\mathrm{CO}_{2}$ for the Hill reaction (Ables, Brown \& Mayne, I96I; Good, I963). It needs to be shown, however, whether the $\mathrm{CO}_{2}$ concentration required for nitrate and nitrite assimilation to reach saturation is the same as that required for the Hill reaction. The work of Davis (1953) suggests that substrate amounts of $\mathrm{CO}_{2}$ are required. Losada et al. (I965) did not find any requirement for $\mathrm{CO}_{2}$ in the spinach chloroplast system but they did indicate that it reduced nitrate very slowly when water was the electron donor. They explained this in terms of competition by cyclic electron flow catalysed by the relatively large amounts of flavine mononucleotide which they added.

The apparent failure of CMU to inhibit electron transport (as measured by $\mathrm{O}_{2}$ evolution) and nitrate or nitrite reduction equally, indicates that the system supplying electrons to NADP is different from that supplying electrons to nitrate or nitrite, although in the case of nitrite, both would use ferredoxin as a primary electron acceptor. Although Losada spoke of a new type of non-cyclic photosynthetic phosphorylation it is doubtful if he intended this to be interpreted so broadly. There are two other possible explanations. Czygan (1963) reported that ascorbate might serve as an electron donor to reduce nitrate in Ankistrodesmus braunii in what he termed nonenzymic reduction. If this report is confirmed it would explain insensitivity to CMU as well as variable stoichiometry. Secondly, Grant \& Whatley (1966) showed that CMU did not inhibit ATP production by cyclic photosynthetic phosphorylation, so that if light was required to produce extra ATP for assimilation of nitrate or nitrite, the electrons required being obtained from dark processes, this would explain that effect. The different light saturation requirement is, in a sense simply an extension of the CMU inhibition problem just discussed. Low light intensitites imply low electron flow rates, yet both nitrate and nitrite assimilating systems are saturated at rates well below the maximum, as measured by the carbon-fixing system. Since $\mathrm{CO}_{2}$ was present in these experiments this again implies an electron transport system different in properties from that proposed for reduction of NADP. Alternatively, it implies that nitrate and nitrite reducing systems have a very much higher affinity for electrons, but a lower turnover number than the carbon-assimilating system. This needs to be investigated before it can be accepted as an explanation.

However, while by making these assumptions, it is possible to explain some of the 
results contained in the present paper by Losada's scheme, the failure to observe stoichiometry as predicted by the theory for nitrate reduction remains a serious obstacle. The ranges of values for the $\mathrm{O}_{2}: \mathrm{NO}_{3}$ and $\mathrm{O}_{2}: \mathrm{NO}_{2}$ ratio are too great to be explained by experimental error. It is known from observations that cells low in total nitrogen give values closer to the expected $2 \cdot 0$ figure than those high in total nitrogen; but starving cells by resuspension in nitrate-free medium in the light for 4 to $24 \mathrm{~h}$ did not give any more reproducible results than these given here. It is concluded that the extra oxygen evolution is not perhaps exclusively related to nitrate and nitrite assimilation, at least in Dunaliella tertiolecta. In view of these difficulties a simpler hypothesis would be the assumption that there are two nitrate and nitrite assimilating systems in algae. One may be similar to that found by Losada for spinach chloroplasts and is the system directly responsive to light. A second system is a dark system dependent only upon light for its carbon source to supply energy. These two systems appear to be differentiated by the inhibitors CMU and iodoacetic acid; further separation might be possible by using the technique for whole chloroplast preparation recently worked out by Jeffrey, Ulrich \& Allen (I966). Until these experiments have been done, preferably on several different species, the mode of action of light on nitrate and nitrite assimilation should remain open.

\section{REFERENCES}

Ables, F. B., Brown, A. H. \& MaYne, B. C. (1961). Stimulation of the Hill reaction by carbon dioxide. Pl. Physiol. 36, 202.

BoNGERS, L. S. H. (1958). Kinetic aspects of nitrate reduction. Neth. J. agric. Sci. 6, 79.

BraY, G. (1960). A simple, efficient liquid scintillator for counting aqueous solutions in a liquid scintillation counter. Analyt. Biochem. I, 279.

Burstrom, H. (1943). Photosynthesis and assimilation of nitrate by wheat leaves. K. lantbrHögsk. Annlr. II, I.

CZYGAN, F.C. (1963). Untersuchungen über die Nitratreduktion der Grünalge Ankistrodesmus braunii. Planta 6o, 225.

Davis, E. A. (1953). Nitrate reduction by Chlorella. Pl. Physiol. 28, 539.

Del Campo, F. F., Paneque, A., Ramirez, J. M. \& Losada, M. (1965). Nitrate reduction with molecular hydrogen in a reconstituted enzymic system. Nature, Lond. 205, 387.

Evans, H. J. \& NaSON, A. (1953). Pyridine nucleotide-nitrate reductase from extracts of higher plants. Pl. Physiol. 28, 233.

FujtTA, Y. \& HATTORI, A. (1963). Action spectrum of light induced nitrite reduction in Anabaena cylindrica. J. gen. appl. Microbiol., Tokyo 9, 257.

Gingras, G. \& Lemasson, C. (1965). A study of the mode of action of 3-(4-chlorophenyl)-I, I-dimethylurea on photosynthesis. Biochim. biophys. Acta 109, 67.

Goon, N. E. (1963). Carbon dioxide and the Hill reaction. Pl. Physiol. 38, 298.

GRANT, B. R. \& WhATELY, F. R. (1966). Some factors affecting the onset of cyclic photophosphorylation. In Biochemistry of Chloroplasts. Ed. by T. W. Goodwin, Vol. 2, p. 505. London: Academic Press.

Grasshof, K. (1964). Zur Bestimmung von Nitrat in Meer und Trinkwasser. Kieler Meeresforsch. 20, 5 .

HATTORI, A. (1962). Light induced reduction of nitrate, nitrite and hydroxylamine in a blue green alga, Anabaena cylindrica. Pl. Cell Physiol., Tokyo 3, 355.

HATTORI, A. (1963). Effect of hydrogen on nitrite reduction by Anabaena cylindrica. In Microalgae and Photosynthetic Bacteria. Ed. by Japanese Society of Plant Physiologists, p. 485. Tokyo: University of Tokyo Press.

JefFery, S. W., Ulrich, J. \& Allen, M. B. (I966). Some photochemical properties of chloroplast preparations from the chrysomonad Hymenomonas sp. Biochim. biophys. Acta 112, 35.

KESSLER, E. (1957). Stoffwechselphysiologiche Untersuchungen on Hydrogenase enthaltenden Grünalgen. Arch. Mikrobiol. 27, 166. 
KesSLER, E. (1959). Reduction of nitrate by green algae. Symp. Soc. exp. Biol. r3, 87 .

Kessler, E. (1964). Nitrate assimilation in plants. A. Rev. Pl. Physiol. 15, 57.

KoK, B. (I95I). Photo-induced interaction in metabolism of green plant cells. Symp. Soc. exp. Biol. $5,21 I$.

Losada, M., Ramirez, J. M., Paneque, A. \& Del Campo, F. F. (i965). Light and dark reduction of nitrate in a reconstituted spinach chloroplast system. Biochim. biophys. Acta ro9, 86.

Morris, A. W. \& RILEY, J. P. (I963). Determination of nitrate in sea water. Analytica chim. Acta 29, 272.

Newell, B. \& Dal Pont, G. (1964). Ammonia in sea water. Nature, Lond. 20r, 36.

van Niel, C. B., Allen, M. B. \& Wright, B. E. (I953). On the photochemical reduction of nitrate by algae. Biochim. biophys. Acta r2, 67 .

PAAsche, E. (1965). The effect of 3-(p-chlorophenyl) I, + I, dimethylurea (CMU) on photosynthesis and light dependent coccolith formation in Coccolithus huxleii. Physiologia Pl. 18, 138.

Paneque, A., Ramirez, J. M., Del Campo, F. F. \& Losada, M. (1964). Light and dark reduction of nitrate in a reconstituted enzymic system. $J$. biol. Chem. 239, I737.

Stiller, M. (1966). Hydrogenase mediated nitrite reduction in Chlorella. Pl. Physiol. 4I, 348.

SYretT, P. J. (1962). Nitrogen assimilation. In Physiology and Biochemistry of Algae. Ed. by R. A. Lewin, p. I7I. New York: Academic Press.

Warburg, O. \& Negelein, E. (1920). Über die Reduktion der Saltpetersäure in grünen Zellen. Biochem. Z. II0, 66.

Warburg, O., Krippahl, G. \& Jetschmann, C. (1965). Widerlegung der Photolyse des $\mathrm{H}_{2} \mathrm{O}$ und Beweis der von $\mathrm{CO}_{2}$. Z. Naturf. 20 b, 993.

Whatley, F. R. \& Arnon, D. I. (1963). Photosynthetic phosphorylation in plants. Meth. Enzymol. 5, 308 . 